\title{
Implementation of Simple Additive Weighting Method in Determination of Aid for Students From Low Socio- Economic Status Family
}

\author{
Mohamad Irfan ${ }^{1}$, Hilman Rismana ${ }^{2}$, Muhammad Deden Firdaus ${ }^{3}$, Wisnu Uriawan ${ }^{4}$ \\ \{irfan.bahaf@uinsgd.ac.id ${ }^{1}$, hilmanrismana@gmail.com², deden@uinsgd.ac.id³, \\ wisnu_u@uinsgd.ac.id $\left.{ }^{4}\right\}$ \\ Universitas Islam Negeri Sunan Gunung Djati Bandung ${ }^{1,2,3,4}$ \\ Asia E University Kuala Lumpur Malaysia ${ }^{1}$
}

\begin{abstract}
Assistance for underprivileged students (BSM) is a program from the government given to underprivileged students who excel, the goal is to provide relief in paying school fees. But there are problems in determining BSM, including the distribution of scholarships not on target. Therefore, to obtain better results and overcome these problems, a decision support system is used in determining BSM criteria. This study uses the method of Simple Additive Weighting (SAW), the method is often known as the weighted sum method. By applying the SAW method, it can help in making decisions for prospective poor student beneficiaries appropriately. The final results of this study found that the SAW method was able to overcome the problems in determining BSM with $100 \%$ accuracy.
\end{abstract}

Keywords: Decision Support System, Scholarship, Criteria, Simple Additive Weighting.

\section{Introduction}

Poor Student Aid is a form of material which aims to provide relief in paying school fees for underprivileged students, and to make poor students stay in school, prevent dropouts, attract poor students to stay in school, help students fulfill their learning needs, supporting a nine-year educational program, and helping the smooth running of school program[1]. Some of the results of the research carried out and continued studies in the BSM program show the weaknesses of this program, which found obstacles in distribution so that it was not in line with the main objectives of providing poor students assistance and the accuracy of the target of poor student assistance, where many non-poor households were found accept BSM and inadequate number of students[2]. The target of BSM recipients is still weak where many BSM recipients who are not from poor families are found and many students from poor families do not receive BSM benefits and the manuals used in BSM recipient ranking are many BSM recipients and many criteria indicators[3]. therefore, to obtain better results and overcome these problems, namely by developing an application that implements methods that can facilitate decision making and can help in increasing the targeting accuracy of BSM program recipients. In this study the author tries to use the Simple Additive Weighting method which method is often known as the addition method[4]-[7]. 


\section{SAW Method Data Calculation}

Here are the following criteria that required for taking decision in the process of selection of the underprivileged student scholarship receiver that drawn in Table 3.1:

Table. 1 Criteria Table

\begin{tabular}{lc}
\hline \multicolumn{1}{c}{ Criteria } & Note \\
\hline Presence/Attendance & C1 \\
Status of Student Activeness & C2 \\
Orphan Status & C3 \\
Underprivileged Official Reference & C4 \\
Parents Salary & C5 \\
\hline
\end{tabular}

In the following table below contains weighted values of criteria that has determined by the decision maker. It can be changed as well as necessary and suitable with recent valid provision[5], [8]. The determined values are conduct to put implementation in the under way current system.

Table. 2 Weight Table

\begin{tabular}{cc}
\hline Criteria & Weight \\
\hline C1 & $15 \%$ \\
C2 & $15 \%$ \\
C3 & $20 \%$ \\
C4 & $25 \%$ \\
C5 & $25 \%$ \\
\hline
\end{tabular}

From the criteria above, it has been made some tiers of criteria significance based on alternative values that had determined into point value[9]-[12]. Henceforth, the compatibility rank in each alternative is displayed in the following table 3:

Table. 3 Compatibility Rate

\begin{tabular}{ccccll}
\hline Value & C1 & C2 & C3 & \multicolumn{1}{c}{ C4 } & \multicolumn{1}{c}{ C5 } \\
\hline 10 & $100 \%$ & Active & Yes & Orphan & $>=$ Rp. 2.000.000,- \\
8 & $>=90 \%$ & & & Orphan & Rp. 1.500.000,- s.d Rp. 2.000.000,- \\
6 & $>=75 \%$ & & & & Rp. 1.000.000,- s.d Rp. 1.500.000,- \\
4 & $>=70 \%$ & & & & Rp. 500.000,- s.d Rp. 1.000.000,- \\
0 & $<70 \%$ & Non & No & Not Orphan & $<=$ Rp. 500.000,- \\
\hline
\end{tabular}

According to the criteria and compatibility rate in each alternative toward determined criteria, resulting next phase that is to alternate delineation in every criteria that has converted with point values[11], [13].

Here are the following manual calculation based on the sample case. There are five alternatives contained data as described by the table below: 
Table. 4 Alternative Data

\begin{tabular}{clllll}
\hline Student & Attendance & $\begin{array}{c}\text { Status of Students } \\
\text { Activeness }\end{array}$ & $\begin{array}{c}\text { Underprivileged } \\
\text { official reference }\end{array}$ & $\begin{array}{c}\text { Orphan } \\
\text { Condition }\end{array}$ & Parents Salary \\
\hline A1 & $>=90 \%$ & Active & Yes/Have & Orphan & $<=$ Rp. 500.000,- \\
A2 & $100 \%$ & Active & No/Does not have & Not orphan & $\begin{array}{l}\text { Rp. 500.000,-s.d Rp. } \\
1.000 .000,-\end{array}$ \\
A3 & $100 \%$ & Active & Yes/Have & Not orphan & $<=$ Rp. 500.000,- \\
A4 & $>=70 \%$ & Active & Yes/Have & Orphan & $<=$ Rp. 500.000,- \\
A5 & $0 \%$ & Not Active & No/Does not have & Not Orphan & Rp. 500.000,- s.d Rp. \\
& & & & & $1.000 .000,--$ \\
\hline
\end{tabular}

Here are the step-by-step completion phases of SAW method[14], [15]:

a. Determine the criteria for decision-making. (Criteria)

b. Determine the compatibility rates in each alternative of detremined criteria

c. Making the criteria decision matrix (Ci)

d. Matrix normalization from its similiarity is adjusted into its kind of attribute (profit $/$ max or cost $/ \mathrm{min}$ ) in order to obtain normalized matrix as R. The sum of $\mathrm{R}$ normalized matrix multiplication with weight vector could obtain biggest values that used by proper alternative from other existing alternative (Ai) as the problem solver.

The formula in the process of normalization is in the following:

$$
r_{i j}= \begin{cases}\frac{x_{i j}}{\max x_{i j}} & \text { if } j \text { atribut benef it } \\ \frac{\min x_{i j}}{x_{i j}} & \text { if } j \text { atribut cost }\end{cases}
$$

Notes:

$\mathrm{R}_{\mathrm{ij}}=$ Normalized implementation rate

$\operatorname{Max}_{\mathrm{ij}}=$ Maximum value from each column and row

$\operatorname{Min}_{\mathrm{ij}}=$ Minimum value from each column and row

$\mathrm{X}_{\mathrm{ij}}=$ Column and row of matrix

In addition, $\mathrm{Rij}$ as the normalized implementation rate from $\mathrm{Ai}$ alternative in attribut $\mathrm{Cj}$ :

$\mathrm{i}=1,2 \ldots . . \mathrm{m}$ dan $\mathrm{j}=1,2 \ldots \mathrm{n}$

Preference values for each alternative (Vi) are given half :

Where :

$$
V_{i}=\sum_{j=1}^{n} W j r_{i j}
$$

$\mathrm{V}_{\mathrm{i}}=$ Final value from alternative

$\mathrm{W}_{\mathrm{j}}=$ Determined weight

$\mathrm{R}_{\mathrm{ij}}=$ Normalization

In addition, the bigger Vi value indicates that Ai alternative is more selected.

\section{$5 \quad$ Result and Discussion}

The following table below depicts criteria that required in the decision-making of the selection process of underprivileged student scholarship receiver. The determined caracteria are: 
Table. 5 Criteria

\begin{tabular}{lc}
\hline \multicolumn{1}{c}{ Nama Kriteria } & Keterangan \\
\hline Presence/Attendance & $\mathrm{C} 1$ \\
Status of Student Activeness & $\mathrm{C} 2$ \\
Orphan Condition & $\mathrm{C} 3$ \\
Underprivilege Official Reference & $\mathrm{C} 4$ \\
Parents Salary & $\mathrm{C} 5$ \\
\hline
\end{tabular}

In addition, the table below shows the weight value of criteria that had determined by the decision-maker that can changed as well as the current valid provision. The values has determined to put implementation in the under way system ahead.

Table. 6 Weight

\begin{tabular}{cc}
\hline Criteria & Weight \\
\hline C1 & $15 \%$ \\
C2 & $15 \%$ \\
C3 & $20 \%$ \\
C 4 & $25 \%$ \\
C5 & $25 \%$ \\
\hline
\end{tabular}

Table. 7 Compatibility rate

\begin{tabular}{ccclll}
\hline Value & C1 & C2 & C3 & C4 & \multicolumn{1}{c}{ C5 } \\
\hline 10 & $100 \%$ & Active & Yes/have & Orphan & $>=2.000 .000,-$ \\
8 & $>=90 \%$ & & & Orphan & Rp. 1.500.000,- s.d Rp. 2.000.000,- \\
6 & $>=75 \%$ & & & & Rp. 1.000.000,- s.d Rp. 1.500.000,- \\
4 & $>=70 \%$ & & & Rp. 500.000,- s.d Rp. 1.000.000,- \\
0 & $<70 \%$ & Not active & No/Does not have & Not orphan & $<=$ Rp. 500.000,- \\
\hline
\end{tabular}

Based on the criteria and compatibility rate in each alternative towards determined criteria that it has drawn the alternative description in each converted criteria with the point values.

Here are the following manual calculation based on the case sample. There are five alternatives had data as described below:

Table. 8 Compatibility Rate from each alternatives in criteria

\begin{tabular}{cccccc}
\hline Alternative & C1 & C2 & C3 & C4 & C5 \\
\hline A1 & 8 & 10 & 10 & 8 & 2 \\
A2 & 10 & 10 & 2 & 2 & 4 \\
A3 & 10 & 10 & 10 & 2 & 2 \\
A4 & 4 & 10 & 10 & 8 & 2 \\
A5 & 2 & 2 & 2 & 2 & 4 \\
\hline
\end{tabular}

Its calculation based on matrix formula :

From C1 : 


$$
\begin{aligned}
& A 1=\frac{8}{\operatorname{Max}\{8,10,10,4,2\}}=\frac{8}{10}=0.8 \\
& A 2=\frac{10}{\operatorname{Max}\{8,10,10,4,2\}}=\frac{10}{10}=1 \\
& A 3=\frac{10}{\operatorname{Max}\{8,10,10,4,2\}}=\frac{10}{10}=1 \\
& A 4=\frac{4}{\operatorname{Max}\{8,10,10,4,2\}}=\frac{4}{10}=0.4 \\
& A 5=\frac{2}{\operatorname{Max}\{8,10,10,4,2\}}=\frac{2}{10}=0.2
\end{aligned}
$$

From $\mathrm{C} 2$ :

$$
\begin{aligned}
& A 1=\frac{10}{\operatorname{Max}\{10,10,10,4,2\}}=\frac{10}{10}=1 \\
& A 2=\frac{10}{\operatorname{Max}\{10,10,10,4,2\}}=\frac{10}{10}=1 \\
& A 3=\frac{10}{\operatorname{Max}\{10,10,10,4,2\}}=\frac{10}{10}=1 \\
& A 4=\frac{10}{\operatorname{Max}\{10,10,10,4,2\}}=\frac{10}{10}=1 \\
& A 5=\frac{2}{\operatorname{Max}\{10,10,10,4,2\}}=\frac{2}{10}=0.2
\end{aligned}
$$

From C3 :

$$
\begin{aligned}
& A 1=\frac{10}{\operatorname{Max}\{10,2,10,10,2\}}=\frac{10}{10}=1 \\
& A 2=\frac{2}{\operatorname{Max}\{10,2,10,10,2\}}=\frac{2}{10}=0.2 \\
& A 3=\frac{10}{\operatorname{Max}\{10,2,10,10,2\}}=\frac{10}{10}=1 \\
& A 4=\frac{10}{\operatorname{Max}\{10,2,10,10,2\}}=\frac{10}{10}=1 \\
& A 5=\frac{2}{\operatorname{Max}\{10,2,10,10,2\}}=\frac{2}{10}=0.2
\end{aligned}
$$

From $\mathrm{C} 4$ :

$$
\begin{aligned}
& A 1=\frac{8}{\operatorname{Max}\{8,2,2,8,2\}}=\frac{8}{8}=1 \\
& A 2=\frac{2}{\operatorname{Max}\{8,2,2,8,2\}}=\frac{2}{8}=0.25 \\
& A 3=\frac{2}{\operatorname{Max}\{8,2,2,8,2\}}=\frac{2}{8}=0.25 \\
& A 4=\frac{\frac{2}{\operatorname{Max}\{8.2,2,8,2\}}=\frac{8}{8}=1}{}
\end{aligned}
$$




$$
A 5=\frac{2}{\operatorname{Max}\{8,2,2,8,2\}}=\frac{2}{8}=0.25
$$

From C5 :

$$
\begin{aligned}
& A 1=\frac{\min \{2,4,2,2,4\}}{2}=\frac{2}{2}=1 \\
& A 2=\frac{\min \{2,4,2,2,4\}}{4}=\frac{2}{4}=0.5 \\
& A 3=\frac{\min \{2,4,2,2,4\}}{2}=\frac{2}{2}=1 \\
& A 4=\frac{\min \{2,4,2,2,4\}}{2}=\frac{2}{2}=1 \\
& A 5=\frac{\min \{2,4,2,2,4\}}{4}=\frac{2}{4}=0.5
\end{aligned}
$$

Then, it acquires normalized matrix values as follows:

$$
\mathrm{R}=\left[\begin{array}{ccccc}
0.8 & 1 & 1 & 1 & 1 \\
1 & 1 & 0.2 & 0.25 & 0.5 \\
1 & 1 & 1 & 0.25 & 1 \\
0.4 & 1 & 1 & 1 & 1 \\
02 & 0.2 & 0.2 & 0.25 & 0.5
\end{array}\right]
$$

The next stage is to conduct preference values for each alternative (Vi) by sum the result from normalized matrix multiplication $(\mathrm{R})$ with the weight value $(\mathrm{W})$. Then, the bigger Vi value indicates that (Ai) alternative is the most selected.

$$
\mathrm{W}=\left[\begin{array}{lllll}
0.15 & 0.15 & 0.20 & 0.25 & 0.25
\end{array}\right]
$$

Then, the preference values as follows :

$$
\begin{aligned}
\mathrm{V} 1 & =(0.8 \times 0.15)+(1 \times 0.15)+(1 \times 0.20)+(1 \times 0.25)+(1 \times 0.25)=0.97 \\
\mathrm{~V} 2 & =(1 \times 0.15)+(1 \times 0.15)+(0.2 \times 0.20)+(0.25 \times 0.25)+(0.5 \times 0.25)=0.528 \\
\mathrm{~V} 3 & =(1 \times 0.15)+(1 \times 0.15)+(1 \times 0.20)+(0.5 \times 0.25)+(1 \times 0.25)=0.8113 \\
\mathrm{~V} 4 & =(0.4 \times 0.15)+(1 \times 0.15)+(1 \times 0.20)+(1 \times 0.25)+(1 \times 0.25)=0.91 \\
\mathrm{~V} 5 & =(0.2 \times 0.15)+(0.2 \times 0.15)+(0.2 \times 0.20)+(0.25 \times 0.25)+(0.5 \times 0.25)=0.288
\end{aligned}
$$

The final step is the ranking process.

Here are the following results that acquired some of the biggest values:

Table. 9 Ranking Result

\begin{tabular}{ccc}
\hline Ranking & Alternative (student) & Value \\
\hline 1 & A1 & 0.97 \\
2 & A4 & 0.91 \\
3 & A3 & 0.811 \\
4 & A2 & 0.528 \\
5 & A5 & 0.288 \\
\hline
\end{tabular}




\section{Conclusion}

In sum up, after implementation of Simple Additive Weighting (SAW) method in the support system of decision determination regarding underprivileged student aid, it could be concluded that this system is produce decision in the form of student ranking list which is contain some of the list of student that proper to get the aid as well as suitable with the determined criteria. Based on the previous conducted test result, from 20 people as the sample data which consists of underprivileged aid receiver candidates, shows that the accuracy level up to $100 \%$. This result however illustrated that this implementation of Simple Additive Weighting (SAW) method in recent system is reach its succeed-rate and it works well.

Last but not least, this support system of decision determination in selection of underprivileged student aid is still far from perfect because it is using only one method as well as its existing system still manual. The developer could make some system that compares one method with another. Further conclusion and suggestion are highly required to this research.

\section{References}

[1] Undang-undang Republik Indonesia, "Undang-Undang Republik Indonesia Nomor 12 Tahun 2012 tentang Pendidikan Tinggi," pp. 1-97, 2012.

[2] R. Fauzan, Y. Indrasary, and N. Muthia, "Sistem Pendukung Keputusan Penerimaan Beasiswa Bidik Misi di POLIBAN dengan Metode SAW Berbasis Web," J. Online Inform., vol. 2, no. 2, p. 79, 2018.

[3] I. Taufik, U. Syaripudin, and J. Jumadi, "Implementasi Metode Promethee Untuk Menentukan Penerima Beasiswa," J. Istek, vol. 10, no. 1, 2017.

[4] M. S. D. Utomo, "Penerapan Metode Saw ( Simple Additive Weight ) Pada Sistem Pendukung Keputusan Untuk Pemberian Beasiswa Pada Sma Negeri 1 Cepu Jawa Tengah,” Fak. Ilmu Komput. Univ. Dian Nuswantoro, Semarang, 2015.

[5] J. Kittur, "Optimal generation evaluation using SAW, WP, AHP and PROMETHEE multi - Criteria decision making techniques," in Proceedings of IEEE International Conference on Technological Advancements in Power and Energy, TAP Energy 2015, 2015, pp. 304-309.

[6] A. R. Afshari, R. Yusuff, and A. R. Derayatifar, "Project Manager Selection by Using Fuzzy Simple Additive Weighting Method," in 2012 International Conference on Innovation Management and Technology Research, 2012, pp. 412-416.

[7] I. Septiana, M. Irfan, A. R. Atmadja, and B. Subaeki, "Sistem Pendukung Keputusan Penentu Dosen Penguji Dan Pembimbing Tugas Akhir Menggunakan Fuzzy Multiple Attribute Decision Makingdengan Simple Additive Weighting (Studi Kasus: Jurusan Teknik Informatika Uin Sgd Bandung)," JOIN (Jurnal Online Inform., vol. 1, no. 43-50, 2016.

[8] I. Irvanizam, "Multiple attribute decision making with simple additive weighting approach for selecting the scholarship recipients at Syiah Kuala university," Proc. - 2017 Int. Conf. Electr. Eng. Informatics Adv. Knowledge, Res. Technol. Humanit. ICELTICs 2017, vol. 2018-Janua, no. ICELTICs, pp. 245-250, 2018.

[9] A. J. Chabuk, N. Al-Ansari, H. M. Hussain, S. Knutsson, and R. Pusch, "GIS-based assessment of combined AHP and SAW methods for selecting suitable sites for landfill in Al-Musayiab Qadhaa, Babylon, Iraq," Environ. Earth Sci., vol. 76, no. 209, p. 12, 2017.

[10] D. Syahid, Jumadi, and D. Nursantika, "Sistem Klasifikasi Jenis Tanaman Hias Daun Philodendron Menggunakan Metode K-Nearest Neighboor (Knn) Berdasarkan Nilai Hue, Saturation, Value (Hsv)," $J$. Online Inform., vol. 1, no. 1, pp. 20-23, 2016.

[11] T. Susilowati et al., "Determination of scholarship recipients using simple additive weighting method," Int. J. Pure Appl. Math., vol. 119, no. 15, 2018. 
[12] A. Pranolo and S. M. Widyastuti, "Simple additive weighting method on intelligent agent for urban forest health monitoring," Proceeding - 2014 Int. Conf. Comput. Control. Informatics Its Appl. "New Challenges Oppor. Big Data”, IC3INA 2014, pp. 132-135, 2014.

[13] V. B. Vommi and S. R. Kakollu, "A simple approach to multiple attribute decision making using loss functions," J. Ind. Eng. Int., vol. 13, no. 1, pp. 107-116, 2017.

[14] J.-J. Huang, "Simple Additive Weighting Method," in Multiple Attribute Decision Making, 2011, pp. $55-67$.

[15] W. S. Goodridge, "Sensitivity Analysis Using Simple Additive Weighting Method," Int. J. Intell. Syst. Appl., vol. 8, no. 5, pp. 27-33, 2016. 